\title{
MicroRNA-146b: A Novel Biomarker and Therapeutic Target for Human Papillary Thyroid Cancer
}

\author{
Chen-Kai Chou ${ }^{1,2}$, Rue-Tsuan Liu ${ }^{1}$ and Hong-Yo Kang ${ }^{2,3, *}$ \\ 1 Division of Endocrinology and Metabolism, Department of Internal Medicine, Kaohsiung Chang Gung \\ Memorial Hospital, Chang Gung University College of Medicine, Kaohsiung City 833, Taiwan; \\ chou@adm.cgmh.org.tw (C.-K.C.); ruetsuan@ms2.hinet.net (R.-T.L.) \\ 2 Graduate Institute of Clinical Medical Sciences, Chang Gung University, Kaohsiung City 833, Taiwan \\ 3 Hormone Research Center and Department of Obstetrics and Gynecology, Kaohsiung Chang Gung \\ Memorial Hospital, Chang Gung University College of Medicine, Kaohsiung City 833, Taiwan \\ * Correspondence: hkang3@mail.cgu.edu.tw; Tel.: +886-7-731-7123 (ext. 8898); Fax: +886-7-733-6970 \\ Academic Editor: Andreas Keller \\ Received: 26 January 2017; Accepted: 8 March 2017; Published: 15 March 2017
}

\begin{abstract}
Papillary thyroid cancer (PTC) is the most common tumor subtype of thyroid cancer. However, not all PTCs are responsive to current surgical and radioiodine treatment. The well-established clinical prognostic factors include tumor size, lymph node/distal metastasis, and extrathyroidal invasion. The RET/PTC-RAS-BRAF linear molecular signaling cascade is known to mediate PTC pathogenesis. However, whether presence of $B R A F$ mutation, the most common genetic alteration in PTC, can affect PTC behavior and prognosis is controversial. MicroRNAs (miRNAs) have been labeled as promising molecular prognostic markers in several tumor types. Our recent studies demonstrated that microRNA-146b (miR-146b) deregulation is associated with PTC aggressiveness and prognosis. Here we summarize the current knowledge related to the functional roles, regulated target genes, and clinical applications of miR-146b in PTC and discuss how these studies provide insights into the key role of miR-146b as an oncogenic regulator promoting cellular transformation as well as a prognosis marker for tumor recurrence in PTC. In conjunction with the current perspectives on miRNAs in a wide variety of human cancers, this review will hopefully translate these updated findings on miR-146b into more comprehensive diagnostic or prognostic information regarding treatment in PTC patients before surgical intervention and follow up strategies.
\end{abstract}

Keywords: papillary thyroid carcinoma; microRNA-146b; target gene; tumorigenesis

\section{Introduction}

The prevalence of thyroid cancer has increased over time from the worldwide reports; the majority of thyroid cancers are papillary thyroid carcinoma (PTC), which is clinical-pathogenically heterogeneous in tumor behavior or prognosis [1,2]. Although most of PTCs could be managed successfully with a combination of radioactive iodide and levothyroxine suppression therapy after complete surgical intervention, a certain proportion of PTCs remain irresponsive to treatment and result in comorbidity and mortality. Therefore, it is crucial to further elucidate the pathogenesis of PTC regarding tumor behavior at the molecular level.

In PTCs, rearrangements in RET/PTC and NTRK and point mutations in RAS and BRAF constitutively activate the mitogen-activated protein kinase (MAPK) pathway, which are cumulatively found in over $70 \%$ PTCs [3-5]. Numerous clinicopathological and molecular studies provide compelling genetic evidence that constitutively active MAPK signaling is a key component of thyrocyte transformation in PTC. The most common genetic alteration among these mutations is the BRAF ${ }^{\mathrm{V} 600 \mathrm{E}}$ point mutation, which is demonstrated to be significantly associated with extrathyroidal invasion, 
advanced disease stages, lymph node metastasis, and tumor recurrence in PTC [6]. However, not all studies support the assessment that the $B R A F^{\mathrm{V} 600 \mathrm{E}}$ point mutation is an independent predictor of the disease extent or outcome. Some studies find it not to be predictive at all [7], some find it significant only in univariate but not in multivariate analysis [8], whereas others find it to be useful in addition to other specific clinical and histological features [9]. However, Sancisi et al. [10] studied $B R A F^{\mathrm{V} 600 \mathrm{E}}$ mutation in metastatic PTC and found that the $B R A F^{\mathrm{V} 600 \mathrm{E}}$ mutation was present in $29.8 \%$ of the distantly metastatic PTC, whereas it was detected in about $44.0 \%$ of the control tumors, suggesting that the $B R A F$ mutation was of no significance for active disease progression. Moreover, Guerra et al. [11] demonstrate that clonal $B R A F^{\mathrm{V} 600 \mathrm{E}}$ is a rare occurrence in PTC suggesting that the $B R A F^{\mathrm{V} 600 \mathrm{E}}$ mutation is a late subclonal event in PTC. This evidence supports the concept that the presence of $B R A F$ mutation may not be the fundamental event in tumorigenesis or an independent predictor of outcome. Therefore, identification of a new marker associated with $B R A F$-positive tumors and poor prognosis is required and may serve as a new therapeutic target and follow-up marker in PTC.

MicroRNAs (miRNAs) are small noncoding RNA molecules that function as negative regulators of gene expression by binding to the $3^{\prime}$-untranslated region of candidate mRNAs, and blocking the translation or degradation of target mRNAs that regulate various pathophysiological courses [12]. Regulation of classical oncogenes and tumor suppressor genes by miRNAs was effortlessly identified as a hallmark of cancer research, transforming this class of small RNAs into potential targets for cancer therapy, diagnosis, and prognosis. Recent studies on miRNA deregulation have demonstrated increased aberrant miRNA expression (particularly, miR-222, miR-221, and miR-146b) in PTCs compared to that in normal thyroid tissues [13-15]. These data indicated the distinct miRNA profile associated with PTC carcinogenesis. Furthermore, the deregulation or aberrant expression of several miRNAs in PTC has been implicated in disease development, progression, and prognosis [13,14,16-18]. A microRNA array study [19] demonstrated that deregulation of microRNA-146b (miR-146b) was significantly associated with aggressive tumor behavior in $B R A F$-positive clinical PTC specimens. In the context of $B R A F$ mutation and miR-146b, we noticed that patients harboring $B R A F$ mutations had a higher expression level of miR-146b than that in $B R A F$ wild-type patients [15]. Furthermore, Geraldo et al. [20] demonstrated that transformation of $B R A F$ mutation resulted in significant elevation of miR-146b levels. The discovery of $B R A F-$ miRNA regulation opens a new perspective in the understanding of PTC biology.

\section{Structure, Expression, and Regulation of MicroRNA-146b}

MiR-146a and miR-146b are known as post-transcriptional gene silencers, which play an important role in regulating inflammatory responses [21]. They also share identical sequences except for a difference of two nucleotides in the $3^{\prime}$-end and hence could translationally down-regulate similar candidate genes. Mature forms of miR-146a and miR-146b are encoded by two separate genes-MIR146A and MIR146B-localized to human chromosomes 5 and 10, respectively. The stem-loop structure of pre-miR-146b and the sequences of mature miR-146b are shown in Figure 1 . It is known that miRNAs can be regulated by multiple genes or factors, sequentially or simultaneously, and previous studies have identified the up-stream regulators of miR-146b $[21,22]$. While miR-146b has also been demonstrated as one of the downstream targets of nuclear factor- $\mathrm{kB}(\mathrm{NF}-\mathrm{kB})$ signaling and is up-regulated by toll-like receptor ligand treatment as well as in response to tumor necrosis factor $\alpha$ or interleukin-1 $\beta$ stimulation [21]. Furthermore, PDGF (platelet-derived growth factor) regulates the transcription of miR-146b and provides evidence for a miR-dependent feedback mechanism balancing growth factor receptor signaling in cancer cells [22]. 


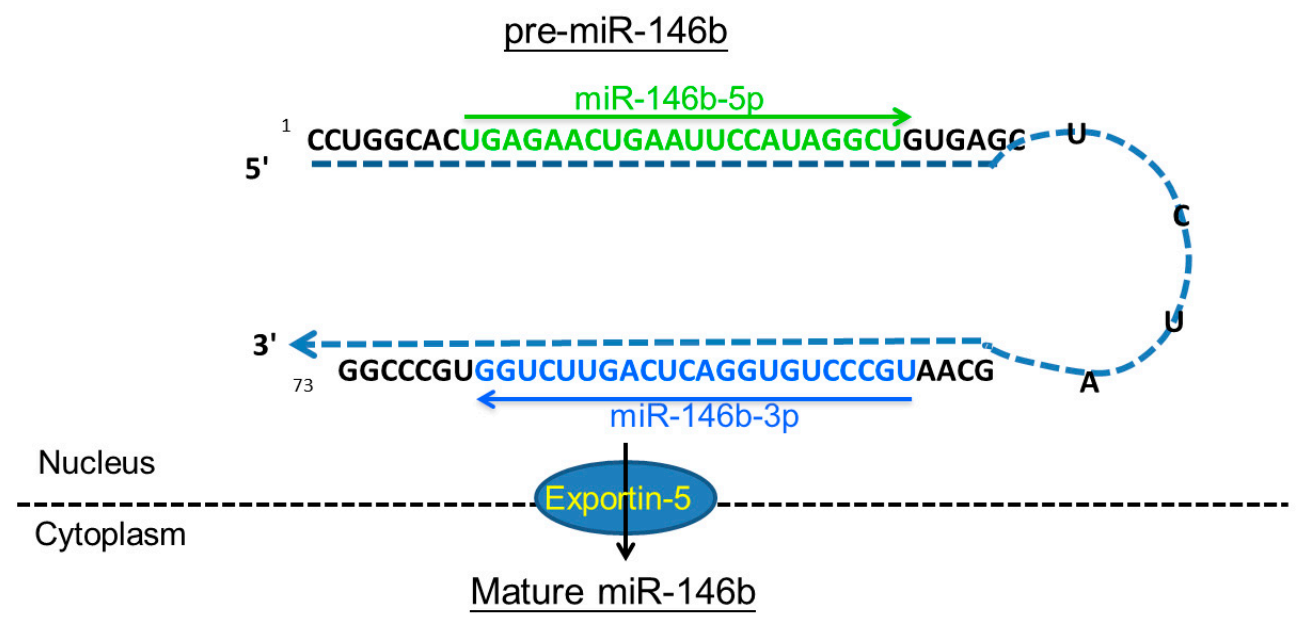

miR-146b-5p : 5'-UGAGAACUGAAUUCCAUAGGCU-3'

miR-146b-3p : 5'-UGCCCUGUGGAUCAGUUCUGG-3'

Figure 1. The hairpin structure of pre-miR-146b and the sequence of mature miR-146b. The MIR146B gene is located in an intergenic region of chromosome 10q24.32 and transcribed into a precursor (pre-miR-146b) with 73 nucleotides in the nucleus, that is exported to the cytoplasm by Exportin-5 for additional processing to yield two mature microRNAs with 22 nucleotides, miR-146b-5p and miR-146b-3p. The sequence of mature miR-146b-5p and miR-146b-3p is colored in green and blue. The arrow shows the orientations from $5^{\prime}$ to $3^{\prime}$.

Differential miR-146b expression between normal thyroid tissue and PTC has been shown previously $[13,15,17,23-25]$. On the basis of histological features, emerging evidence indicates that dysregulated miR-146b is implicated in the different variants of PTC. PTC is a very heterogeneous group of tumors that can be further categorized into several subtypes: such as classical variant of PTC (cPTC), follicular variant of PTC (fvPTC), and tall cell variant (tcPTC). A recent study analyzed the datasets of 466 thyroid cancer samples sequenced in The Cancer Genome Atlas (TCGA) and showed that the expression level of miR-146b is higher in $\mathrm{CPTC}$ than $\mathrm{fvPTC}$, but no significant difference was noted between cPTC and tcPTC [26]. The similar expression level of miR-146b in infiltrative fvPTC and noninvasive follicular thyroid tumor with papillary-like nuclear features (NIFTP) was also reported recently [27].

A genomic, epigenomic, and proteomic profiling of a large cohort of PTC patients reveals that several microRNAs including miR-146b are classified as oncomirs, which are associated with metastasis [28]. Several studies have suggested that elevated miR-146b expression may play a role in advanced malignant tumor characteristics [15,19,24,29-31], including extra-thyroidal invasion and advanced stages of PTC. Furthermore, several recent studies, including our own, have provided evidence that miR-146b overexpression even plays a critical role in PTC progression and patient prognosis [32,33]. Overexpression of miR-146 has also been observed in follicular thyroid carcinoma (FTC) [34] and poorly differentiated thyroid carcinoma [35], suggesting that this miRNA is full of potential to be further investigated its pathogenesis roles in the malignant thyroid neoplasms.

\section{Cellular Functions of miRNA-146b in Papillary Thyroid Carcinoma (PTC)}

Despite significant progress in the knowledge about miR-146b deregulation in thyrocyte transformation, there is much more to elucidate about the signal transduction of miR-146b regulatory mechanisms and their functional impact in PTC cells. A number of studies related to the roles of miR-146b-regulated genes in enhancing PTC behavior are listed in Table 1. Geraldo et al. [20] reported that overexpression of miR-146b suppressed SMAD4 (SMAD family member 4) expression, 
thereby leading to up-regulated resistance against TGF- $\beta$-mediated cell cycle arrest in PTC cell line. Deng et al. [36] demonstrated the involvement of miR-146b-ZNRF3 signal transductions in epithelial-mesenchymal transition (EMT) through modulation of Wnt/ $\beta$-catenin signaling. In order to delineate the role of miR-146b in EMT by augmenting PTC cancer cell migration/invasion, we identified a regulatory mechanism linking miR-146b and its target gene IRAK1 in PTC cell lines [37]. The function of the miR-146b-IRAK1 axis may be potentially associated with EMT by regulation of E-cadherin in PTC cancer cell lines. We also confirmed that miR-146b promotes aggressive tumor characteristics in PTC by suppressing IRAK1 expression and that restoration of IRAK1 expression reversed this outcome. In agreement with our findings, Lima et al. [38] reported that miR-146b positively regulates migration and invasion activity both in normal or cancer thyroid lines through the action of stimulating actin cytoskeleton functions. In addition, miR-146b and its related target genes play an important role in other thyroid neoplasms. The expression level of miR-146b has been proved to be negatively regulated by $H D A C 3$ and inhibition of miR-146b expression increased the radioactive iodide sensitivity by regulating the sodium/iodide symporter (NIS) expression in poorly differentiated thyroid cancer cells [35]. Riesco-Eizaguirre et al. [39] stated that miR-146b binds to the $3^{\prime}$-untranslated region of $P A X 8$ and NIS, thus repressing iodide protein translation and leading to insensitivity to radioactive iodide treatment. Wang et al. [40] reported that p21 is regulated by miR-146b and leads to tumor proliferation and migration in anaplastic thyroid cancer (ATC) cells. However, there are conflicting reports for miR-146b in other solid neoplasms. Bhaumik et al. [41] found that miR-146b expression suppresses NF-KB activity and reduces metastatic potential in human breast cancer cell lines. Moreover, the expression of epidermal growth factor receptor (EGFR) in human glioblastoma cell lines was suppressed by miR-146b, which reduced their migration and invasion in vitro [42]. While the activity and biological function of miR-146b behaving either as an oncogene or tumor suppressor depending on different types of cancer is not well-understood, it is conceivable that the miR-146b may interact with different cancer-specific cellular and molecular context to regulate its specific target genes and to determine the functions of miRNA-target interaction regulatory networks in specific tumor microenvironment.

Table 1. Summary of miR-146b regulatory molecules and their effects in thyroid cancer cell lines.

\begin{tabular}{|c|c|c|c|c|c|c|}
\hline $\begin{array}{c}\text { Regulatory } \\
\text { Molecule/Pathway }\end{array}$ & Action & Function & $\begin{array}{l}\text { Direct/ } \\
\text { Indirect }\end{array}$ & Cancer Cell Line & Cancer Subtype & Reference \\
\hline $\begin{array}{l}\text { Downregulated } \\
\text { SMAD4 }\end{array}$ & $\begin{array}{l}\text { Inhibit TGF- } \beta \\
\text { anti-signal }\end{array}$ & $\begin{array}{c}\text { Increase proliferation } \\
\text { activity Inhibit cell } \\
\text { cycle arrest }\end{array}$ & Direct & TPC- 1 and BCPAP & PTC & [20] \\
\hline Downregulated NIS & $\begin{array}{c}\text { HDAC3 } \\
\text { suppresses } \\
\text { miR-146b }\end{array}$ & $\begin{array}{l}\text { Decrease sensitivity to } \\
\text { radioactive iodide }\end{array}$ & Direct & FTC-133 & $\begin{array}{l}\text { Poorly differential } \\
\text { thyroid carcinoma }\end{array}$ & [35] \\
\hline $\begin{array}{l}\text { Downregulated } \\
\text { IRAK1 }\end{array}$ & $\begin{array}{l}\text { Associated } \\
\text { with EMT } \\
\text { process }\end{array}$ & $\begin{array}{l}\text { Increase migration, } \\
\text { proliferation }\end{array}$ & Direct & BCPAP and TPC-1 & PTC & [37] \\
\hline
\end{tabular}

Papillary thyroid cancer; ATC, anaplastic thyroid cancer; FTC, follicular thyroid carcinoma; EMT, epithelialmesenchymal transition.

\section{Clinical Applications of MicroRNA-146b in PTC}

It is believed that miRNAs are more stable than mRNA, thus the clinical application of miRNA detection can be easily used in clinical specimens like plasma or serum. An emerging number of studies [17,43-46] have reported that several distinct miRNA panels, which include miR-146b, 
could distinguish malignant tissues from benign lesions in thyroid fine-needle aspiration (FNA) specimens via quantitative polymerase chain reaction. Furthermore, circulating miR-146b expression was demonstrated as a convenient and useful serological marker to discriminate between PTC and benign lesions or healthy individuals $[47,48]$. Detection of miR-146b expression by in situ hybridization analysis has also shown unique diagnostic value in distinguishing PTC from FTC and ATC [49]. Furthermore, The Cancer Genome Atlas (TCGA) has suggested that the potential miR-146b-IRAK1 regulation characterizes classic PTC subtype [26].

Although clinical applications concerning miR-146b levels in pre-operation thyroid tissue remain unclear, our study demonstrated the prognostic prediction value of miR-146b expression by long term follow up [32]. Furthermore, in patients undergoing prophylactic central neck lymph node dissections, miR-146b is identified as potential markers of central neck lymph node metastasis [50]. Thus, the status of miR-146b expression appears to have supplementary diagnostic value and provides more comprehensive information regarding patient's condition before surgical intervention. The clinical applications of miR-146b in PTC are shown as Table 2.

Table 2. Clinical applications of highly expressed miR-146b in PTC.

\begin{tabular}{|c|c|c|c|}
\hline Mode of Implication & Specimens & Experiments & Reference \\
\hline Predicts the poor prognosis & Thyroid cancer tissue & $\begin{array}{l}\text { Quantitative polymerase } \\
\text { chain reaction }\end{array}$ & {$[32]$} \\
\hline $\begin{array}{c}\text { Differentiates malignancy from } \\
\text { benign lesions }\end{array}$ & Thyroid fine needle aspiration & $\begin{array}{l}\text { Quantitative polymerase } \\
\text { chain reaction }\end{array}$ & {$[43-45]$} \\
\hline $\begin{array}{l}\text { Distinguishes between benign } \\
\text { and malignant }\end{array}$ & Plasma & $\begin{array}{l}\text { Quantitative polymerase } \\
\text { chain reaction }\end{array}$ & {$[47]$} \\
\hline $\begin{array}{l}\text { Acts as biomarkers for the } \\
\text { PTC recurrence }\end{array}$ & $\begin{array}{l}\text { Thyroid cancer tissue } \\
\text { and plasma }\end{array}$ & $\begin{array}{l}\text { Quantitative polymerase } \\
\text { chain reaction }\end{array}$ & {$[48]$} \\
\hline $\begin{array}{c}\text { Distinguishes PTC from FTC } \\
\text { and ATC }\end{array}$ & Thyroid cancer tissue & $\begin{array}{c}\text { In Situ Hybridization } \\
\text { Analysis }\end{array}$ & {$[49]$} \\
\hline $\begin{array}{l}\text { Characterizes classic } \\
\text { PTC subtypes }\end{array}$ & Thyroid cancer tissue & $\begin{array}{l}\text { Quantitative polymerase } \\
\text { chain reaction }\end{array}$ & {$[26]$} \\
\hline $\begin{array}{l}\text { Predicts central neck lymph node } \\
\text { metastasis preoperatively }\end{array}$ & Thyroid cancer tissue & $\begin{array}{l}\text { Quantitative polymerase } \\
\text { chain reaction }\end{array}$ & {$[50]$} \\
\hline
\end{tabular}

\section{Conclusions}

The accumulating reports raise an appealing concept that sequence-specific inhibition of miRs in stem/progenitor cell populations can deliver a potential therapeutic strategy for modulation of stem/progenitor cells whose miRs are deregulated in cancer. In the study by Hardin et al., PTC cells acquired increased cancer stem cell-like features and the expression of miR-146b and PRRX1, an EMT marker, was markedly up-regulated [51]. Knockdown of miR-146b had an inhibitory role during TGF- $\beta 1$-induced EMT, suggesting therapeutic potential for such modulation. It is likely that modulation of miR-146b may sensitize stem/progenitor cells in aggressive PTC that remain resistant to the treatment of radioactive iodide and levothyroxine suppression therapy after complete surgical intervention. It will be of great interest to investigate whether targeting miR-146b in PTC is one of the key approaches that enhance susceptibility of cancer stem/progenitor cells to radio-therapeutic treatments. Clearly, understanding the molecular basis involved in the development and aggravation of PTC will be helpful for identifying novel diagnostic, prognostic, and therapeutic targets. Although the exact mechanisms and clinical applications of miR-146b are yet to be fully elucidated, miR-146b expression in PTC not only provides a unique supplemental tool for diagnosis and predicting prognosis, it may also serve as a novel biomarker and therapeutic target for PTC in the near future. 
Acknowledgments: This work was supported by a grant from the Chang Gung Memorial Hospital-Kaohsiung Medical Center, Kaohsiung, Taiwan (Contract no. CMRPG8A0662, CMRPG8E1161-3, CMRPD8F0171-3, CMRPD8D0471-3) and the Ministry of Science and Technology of the Republic of China, Taiwan (Contract no. NSC102-2314-B-182A-088-MY2 and 104-2320-B-182-013-MY3).

Conflicts of Interest: The authors declare no conflict of interest.

\section{Abbreviations}

$\begin{array}{ll}\text { ATC } & \text { Anaplastic thyroid cancer } \\ \text { CPTC } & \text { Classical variant of PTC } \\ \text { fvPTC } & \text { Follicular variant of PTC } \\ \text { EGFR } & \text { Epidermal growth factor receptor } \\ \text { FTC } & \text { Follicular thyroid carcinoma } \\ \text { FNA } & \text { Fine-needle aspiration } \\ \text { EMT } & \text { Epithelial-mesenchymal transition } \\ \text { miRNAs } & \text { MicroRNAs } \\ \text { MAPK } & \text { Mitogen-activated protein kinase } \\ \text { NIFTP } & \text { Noninvasive follicular thyroid tumor with papillary-like nuclear features } \\ \text { NF- } k B & \text { Nuclear factor-kB } \\ \text { PTC } & \text { Papillary thyroid cancer } \\ \text { PDGF } & \text { Platelet-derived growth factor } \\ \text { NIS } & \text { Sodium/iodide symporter }\end{array}$

\section{References}

1. Jung, C.K.; Little, M.P.; Lubin, J.H.; Brenner, A.V.; Wells, S.A., Jr.; Sigurdson, A.J.; Nikiforov, Y.E. The increase in thyroid cancer incidence during the last four decades is accompanied by a high frequency of $B R A F$ mutations and a sharp increase in RAS mutations. J. Clin. Endocrinol. Metab. 2014, 99, E276-E285. [CrossRef] [PubMed]

2. Sipos, J.A.; Mazzaferri, E.L. Thyroid cancer epidemiology and prognostic variables. Clin. Oncol. 2010, 22, 395-404. [CrossRef] [PubMed]

3. Nikiforova, M.N.; Kimura, E.T.; Gandhi, M.; Biddinger, P.W.; Knauf, J.A.; Basolo, F.; Zhu, Z.; Giannini, R.; Salvatore, G.; Fusco, A.; et al. BRAF mutations in thyroid tumors are restricted to papillary carcinomas and anaplastic or poorly differentiated carcinomas arising from papillary carcinomas. J. Clin. Endocrinol. Metab. 2003, 88, 5399-5404. [CrossRef] [PubMed]

4. Kimura, E.T.; Nikiforova, M.N.; Zhu, Z.; Knauf, J.A.; Nikiforov, Y.E.; Fagin, J.A. High prevalence of $B R A F$ mutations in thyroid cancer: Genetic evidence for constitutive activation of the RET/PTC-RAS-BRAF signaling pathway in papillary thyroid carcinoma. Cancer Res. 2003, 63, 1454-1457. [PubMed]

5. Liu, R.T.; Chen, Y.J.; Chou, F.F.; Li, C.L.; Wu, W.L.; Tsai, P.C.; Huang, C.C.; Cheng, J.T. No correlation between $B R A F^{\mathrm{V} 600 \mathrm{E}}$ mutation and clinicopathological features of papillary thyroid carcinomas in Taiwan. Clin. Endocrinol. 2005, 63, 461-466. [CrossRef] [PubMed]

6. Xing, M. BRAF mutation in papillary thyroid cancer: Pathogenic role, molecular bases, and clinical implications. Endocr. Rev. 2007, 28, 742-762. [CrossRef] [PubMed]

7. Fugazzola, L.; Puxeddu, E.; Avenia, N.; Romei, C.; Cirello, V.; Cavaliere, A.; Faviana, P.; Mannavola, D.; Moretti, S.; Rossi, S.; et al. Correlation between $B-R A F^{\mathrm{V} 600 \mathrm{E}}$ mutation and clinico-pathologic parameters in papillary thyroid carcinoma: Data from a multicentric Italian study and review of the literature. Endocr. Relat. Cancer 2006, 13, 455-464. [CrossRef] [PubMed]

8. Handkiewicz-Junak, D.; Czarniecka, A.; Jarzab, B. Molecular prognostic markers in papillary and follicular thyroid cancer: Current status and future directions. Mol. Cell. Endocrinol. 2010, 322, 8-28. [CrossRef] [PubMed]

9. Ricarte-Filho, J.; Ganly, I.; Rivera, M.; Katabi, N.; Fu, W.; Shaha, A.; Tuttle, R.M.; Fagin, J.A.; Ghossein, R. Papillary thyroid carcinomas with cervical lymph node metastases can be stratified into clinically relevant prognostic categories using oncogenic $B R A F$, the number of nodal metastases, and extra-nodal extension. Thyroid 2012, 22, 575-584. [CrossRef] [PubMed] 
10. Sancisi, V.; Nicoli, D.; Ragazzi, M.; Piana, S.; Ciarrocchi, A. BRAF ${ }^{\mathrm{V} 600}$ mutation does not mean distant metastasis in thyroid papillary carcinomas. J. Clin. Endocrinol. Metab. 2012, 97, E1745-E1749. [CrossRef] [PubMed]

11. Guerra, A.; Sapio, M.R.; Marotta, V.; Campanile, E.; Rossi, S.; Forno, I.; Fugazzola, L.; Budillon, A.; Moccia, T.; Fenzi, G.; et al. The primary occurrence of $B R A F^{\mathrm{V} 600}$ is a rare clonal event in papillary thyroid carcinoma. J. Clin. Endocrinol. Metab. 2012, 97, 517-524. [CrossRef] [PubMed]

12. Bartel, D.P. MicroRNAs: Genomics, biogenesis, mechanism, and function. Cell 2004, 116, 281-297. [CrossRef]

13. He, H.; Jazdzewski, K.; Li, W.; Liyanarachchi, S.; Nagy, R.; Volinia, S.; Calin, G.A.; Liu, C.G.; Franssila, K.; Suster, S.; et al. The role of microRNA genes in papillary thyroid carcinoma. Proc. Natl. Acad. Sci. USA 2005, 102, 19075-19080. [CrossRef] [PubMed]

14. Pallante, P.; Visone, R.; Ferracin, M.; Ferraro, A.; Berlingieri, M.T.; Troncone, G.; Chiappetta, G.; Liu, C.G.; Santoro, M.; Negrini, M.; et al. MicroRNA deregulation in human thyroid papillary carcinomas. Endocr. Relat. Cancer 2006, 13, 497-508. [CrossRef] [PubMed]

15. Chou, C.K.; Chen, R.F.; Chou, F.F.; Chang, H.W.; Chen, Y.J.; Lee, Y.F.; Yang, K.D.; Cheng, J.T.; Huang, C.C.; Liu, R.T. miR-146b is highly expressed in adult papillary thyroid carcinomas with high risk features including extrathyroidal invasion and the $B R A F^{\mathrm{V} 600 \mathrm{E}}$ mutation. Thyroid 2010, 20, 489-494. [CrossRef] [PubMed]

16. Zhang, X.; Li, M.; Zuo, K.; Li, D.; Ye, M.; Ding, L.; Cai, H.; Fu, D.; Fan, Y.; Lv, Z. Upregulated miR-155 in papillary thyroid carcinoma promotes tumor growth by targeting APC and activating Wnt/ $\beta$-catenin signaling. J. Clin. Endocrinol. Metab. 2013, 98, E1305-E1313. [CrossRef] [PubMed]

17. Nikiforova, M.N.; Tseng, G.C.; Steward, D.; Diorio, D.; Nikiforov, Y.E. MicroRNA expression profiling of thyroid tumors: Biological significance and diagnostic utility. J. Clin. Endocrinol. Metab. 2008, 93, 1600-1608. [CrossRef] [PubMed]

18. Swierniak, M.; Wojcicka, A.; Czetwertynska, M.; Stachlewska, E.; Maciag, M.; Wiechno, W.; Gornicka, B.; Bogdanska, M.; Koperski, L.; de la Chapelle, A.; et al. In-depth characterization of the microRNA transcriptome in normal thyroid and papillary thyroid carcinoma. J. Clin. Endocrinol. Metab. 2013, 98, E1401-E1409. [CrossRef] [PubMed]

19. Yip, L.; Kelly, L.; Shuai, Y.; Armstrong, M.J.; Nikiforov, Y.E.; Carty, S.E.; Nikiforova, M.N. MicroRNA signature distinguishes the degree of aggressiveness of papillary thyroid carcinoma. Ann. Surg. Oncol. 2011, 18, 2035-2041. [CrossRef] [PubMed]

20. Geraldo, M.V.; Yamashita, A.S.; Kimura, E.T. MicroRNA miR-146b-5p regulates signal transduction of TGF- $\beta$ by repressing SMAD4 in thyroid cancer. Oncogene 2012, 31, 1910-1922. [CrossRef] [PubMed]

21. Taganov, K.D.; Boldin, M.P.; Chang, K.J.; Baltimore, D. NF-kB-dependent induction of microRNA miR-146, an inhibitor targeted to signaling proteins of innate immune responses. Proc. Natl. Acad. Sci. USA 2006, 103, 12481-12486. [CrossRef] [PubMed]

22. Shao, M.; Rossi, S.; Chelladurai, B.; Shimizu, M.; Ntukogu, O.; Ivan, M.; Calin, G.A.; Matei, D. PDGF induced microRNA alterations in cancer cells. Nucleic Acids Res. 2011, 39, 4035-4347. [CrossRef] [PubMed]

23. Cong, D.; He, M.; Chen, S.; Liu, X.; Liu, X.; Sun, H. Expression profiles of pivotal microRNAs and targets in thyroid papillary carcinoma: An analysis of The Cancer Genome Atlas. Onco Targets Ther. 2015, 8, 2271-2277. [PubMed]

24. Sun, M.; Fang, S.; Li, W.; Li, C.; Wang, L.; Wang, F.; Wang, Y. Associations of miR-146a and miR-146b expression and clinical characteristics in papillary thyroid carcinoma. Cancer Biomark. 2015, 15, 33-40. [CrossRef] [PubMed]

25. Peng, Y.; Li, C.; Luo, D.C.; Ding, J.W.; Zhang, W.; Pan, G. Expression profile and clinical significance of microRNAs in papillary thyroid carcinoma. Molecules 2014, 19, 11586-11599. [CrossRef] [PubMed]

26. Stokowy, T.; Gawel, D.; Wojtas, B. Differences in miRNA and mRNA profile of papillary thyroid cancer variants. Int. J. Endocrinol. 2016, 2016, 1427042. [CrossRef] [PubMed]

27. Borrelli, N.; Denaro, M.; Ugolini, C.; Poma, A.M.; Miccoli, M.; Vitti, P.; Miccoli, P.; Basolo, F. miRNA expression profiling of "noninvasive follicular thyroid neoplasms with papillary-like nuclear features" compared with adenomas and infiltrative follicular variants of papillary thyroid carcinomas. Mod. Pathol. 2017, 30, 39-51. [CrossRef] [PubMed]

28. Cancer Genome Atlas Research Network. Integrated genomic characterization of papillary thyroid carcinoma. Cell 2014, 159, 676-690. 
29. Zhang, J.; Liu, Y.; Liu, Z.; Wang, X.M.; Yin, D.T.; Zheng, L.L.; Zhang, D.Y.; Lu, X.B. Differential expression profiling and functional analysis of microRNAs through stage I-III papillary thyroid carcinoma. Int. J. Med. Sci. 2013, 10, 585-592. [CrossRef] [PubMed]

30. Wang, Z.; Zhang, H.; He, L.; Dong, W.; Li, J.; Shan, Z.; Teng, W. Association between the expression of four upregulated miRNAs and extrathyroidal invasion in papillary thyroid carcinoma. Onco Targets Ther. 2013, 6, 281-287. [CrossRef] [PubMed]

31. Yang, Z.; Yuan, Z.; Fan, Y.; Deng, X.; Zheng, Q. Integrated analyses of microRNA and mRNA expression profiles in aggressive papillary thyroid carcinoma. Mol. Med. Rep. 2013, 8, 1353-1358. [PubMed]

32. Chou, C.K.; Yang, K.D.; Chou, F.F.; Huang, C.C.; Lan, Y.W.; Lee, Y.F.; Kang, H.Y.; Liu, R.T. Prognostic implications of miR-146b expression and its functional role in papillary thyroid carcinoma. J. Clin. Endocrinol. Metab. 2013, 98, E196-E205. [CrossRef] [PubMed]

33. Geraldo, M.V.; Fuziwara, C.S.; Friguglieti, C.U.; Costa, R.B.; Kulcsar, M.A.; Yamashita, A.S.; Kimura, E.T. MicroRNAs miR-146-5p and let-7f as prognostic tools for aggressive papillary thyroid carcinoma: A case report. Arq. Bras. Endocrinol. Metabol. 2012, 56, 552-557. [CrossRef] [PubMed]

34. Wojtas, B.; Ferraz, C.; Stokowy, T.; Hauptmann, S.; Lange, D.; Dralle, H.; Musholt, T.; Jarzab, B.; Paschke, R.; Eszlinger, M. Differential miRNA expression defines migration and reduced apoptosis in follicular thyroid carcinomas. Mol. Cell. Endocrinol. 2014, 388, 1-9. [CrossRef] [PubMed]

35. Li, L.; Lv, B.; Chen, B.; Guan, M.; Sun, Y.; Li, H.; Zhang, B.; Ding, C.; He, S.; Zeng, Q. Inhibition of miR-146b expression increases radioiodine-sensitivity in poorly differential thyroid carcinoma via positively regulating NIS expression. Biochem. Biophys. Res. Commun. 2015, 462, 314-321. [CrossRef] [PubMed]

36. Deng, X.; Wu, B.; Xiao, K.; Kang, J.; Xie, J.; Zhang, X.; Fan, Y. MiR-146b-5p promotes metastasis and induces epithelial-mesenchymal transition in thyroid cancer by targeting ZNRF3. Cell Physiol. Biochem. 2015, 35, 71-82. [CrossRef] [PubMed]

37. Chou, C.K.; Chi, S.Y.; Huang, C.H.; Chou, F.F.; Huang, C.C.; Liu, R.T.; Kang, H.Y. IRAK1, a target of miR-146b, reduces cell aggressiveness of human papillary thyroid carcinoma. J. Clin. Endocrinol. Metab. 2016, 101, 4357-4366. [CrossRef] [PubMed]

38. Lima, C.R.; Geraldo, M.V.; Fuziwara, C.S.; Kimura, E.T.; Santos, M.F. MiRNA-146b-5p upregulates migration and invasion of different papillary thyroid carcinoma cells. BMC Cancer 2016, 16, 108. [CrossRef] [PubMed]

39. Riesco-Eizaguirre, G.; Wert-Lamas, L.; Perales-Paton, J.; Sastre-Perona, A.; Fernandez, L.P.; Santisteban, P. The miR-146b-3p/PAX8/NIS regulatory circuit modulates the differentiation phenotype and function of thyroid cells during carcinogenesis. Cancer Res. 2015, 75, 4119-4130. [CrossRef] [PubMed]

40. Wang, S.; Chen, Y.; Bai, Y. p21 participates in the regulation of anaplastic thyroid cancer cell proliferation by miR-146b. Oncol. Lett. 2016, 12, 2018-2022. [CrossRef] [PubMed]

41. Bhaumik, D.; Scott, G.K.; Schokrpur, S.; Patil, C.K.; Campisi, J.; Benz, C.C. Expression of microRNA-146 suppresses NF- $\mathrm{kB}$ activity with reduction of metastatic potential in breast cancer cells. Oncogene 2008, 27, 5643-5647. [CrossRef] [PubMed]

42. Katakowski, M.; Zheng, X.; Jiang, F.; Rogers, T.; Szalad, A.; Chopp, M. MiR-146b-5p suppresses EGFR expression and reduces in vitro migration and invasion of glioma. Cancer Investig. 2010, 28, 1024-1030. [CrossRef] [PubMed]

43. Shen, R.; Liyanarachchi, S.; Li, W.; Wakely, P.E., Jr.; Saji, M.; Huang, J.; Nagy, R.; Farrell, T.; Ringel, M.D.; de la Chapelle, A.; et al. MicroRNA signature in thyroid fine needle aspiration cytology applied to "atypia of undetermined significance" cases. Thyroid 2012, 22, 9-16. [CrossRef] [PubMed]

44. Keutgen, X.M.; Filicori, F.; Crowley, M.J.; Wang, Y.; Scognamiglio, T.; Hoda, R.; Buitrago, D.; Cooper, D.; Zeiger, M.A.; Zarnegar, R.; et al. A panel of four miRNAs accurately differentiates malignant from benign indeterminate thyroid lesions on fine needle aspiration. Clin. Cancer Res. 2012, 18, 2032-2038. [CrossRef] [PubMed]

45. Panebianco, F.; Mazzanti, C.; Tomei, S.; Aretini, P.; Franceschi, S.; Lessi, F.; di Coscio, G.; Bevilacqua, G.; Marchetti, I. The combination of four molecular markers improves thyroid cancer cytologic diagnosis and patient management. BMC Cancer 2015, 15, 918. [CrossRef] [PubMed]

46. Vriens, M.R.; Weng, J.; Suh, I.; Huynh, N.; Guerrero, M.A.; Shen, W.T.; Duh, Q.Y.; Clark, O.H.; Kebebew, E. MicroRNA expression profiling is a potential diagnostic tool for thyroid cancer. Cancer 2012, 118, 3426-3432. [CrossRef] [PubMed] 
47. Lee, Y.S.; Lim, Y.S.; Lee, J.C.; Wang, S.G.; Park, H.Y.; Kim, S.Y.; Lee, B.J. Differential expression levels of plasma-derived miR-146b and miR-155 in papillary thyroid cancer. Oral Oncol. 2015, 51, 77-83. [CrossRef] [PubMed]

48. Lee, J.C.; Zhao, J.T.; Clifton-Bligh, R.J.; Gill, A.; Gundara, J.S.; Ip, J.C.; Glover, A.; Sywak, M.S.; Delbridge, L.W.; Robinson, B.G.; et al. MicroRNA-222 and microRNA-146b are tissue and circulating biomarkers of recurrent papillary thyroid cancer. Cancer 2013, 119, 4358-4365. [CrossRef] [PubMed]

49. Guo, Z.; Hardin, H.; Montemayor-Garcia, C.; Asioli, S.; Righi, A.; Maletta, F.; Sapino, A.; Lloyd, R.V. In situ hybridization analysis of miR-146b-5p and miR-21 in Thyroid nodules: Diagnostic implications. Endocr. Pathol. 2015, 26, 157-163. [CrossRef] [PubMed]

50. Han, P.A.; Kim, H.S.; Cho, S.; Fazeli, R.; Najafian, A.; Khawaja, H.; McAlexander, M.; Dy, B.; Sorensen, M.; Aronova, A.; et al. Association of $B R A F^{\mathrm{V} 600 \mathrm{E}}$ mutation and microRNA expression with central lymph node metastases in papillary thyroid cancer: A prospective study from four endocrine surgery centers. Thyroid 2016, 26, 532-542. [PubMed]

51. Hardin, H.; Guo, Z.; Shan, W.; Montemayor-Garcia, C.; Asioli, S.; Yu, X.M.; Harrison, A.D.; Chen, H.; Lloyd, R.V. The roles of the epithelial-mesenchymal transition marker PRRX1 and miR-146b-5p in papillary thyroid carcinoma progression. Am. J. Pathol. 2014, 184, 2342-2354. [CrossRef] [PubMed]

(C) 2017 by the authors. Licensee MDPI, Basel, Switzerland. This article is an open access article distributed under the terms and conditions of the Creative Commons Attribution (CC BY) license (http:/ / creativecommons.org/licenses/by/4.0/). 